\title{
Foreign Investment Choices and Corporate Governance Role
}

\section{Ayda Farhan ${ }^{1 *}$ and Hairul Azlan Bin Annuar ${ }^{2}$}

${ }^{1}$ Higher Colleges of Technology, UAE

2International Islamic University Malaysia, Malaysia

\begin{abstract}
Countries are encouraging firms to adopt corporate governance mechanisms to enhance monitoring over firms and at the same time to achieve economic growth. This study investigated the effect of the CGC on foreign ownership. Particularly, the study aims to investigate board independence, board size, and audit committee characteristics have an effect on foreign investment in domestic UAE firms. Using panel data analysis, the study was based on a sample from the UAE financial market. The study is based on 72 sampled firms from 2010 to 2013. The findings indicated the importance of corporate governance in the UAE in attracting foreign ownership. Mainly, board size and AC independence had a significant positive effect on attracting foreign investments. While, foreign investors, who considered it an indicator of weak supervision, did not prefer board independence. The current study contributes to the literature related to the professional practice of corporate governance by introducing the role of corporate governance and consequences in the firms. Moreover, this study studied the preferences of foreign ownership in absence of firms' performance factor. The results of this study have major implication that corporate governance application should concentrate on the mechanisms that could achieve the intended goal.
\end{abstract}

Keywords: Corporate governance; Foreign ownership; Income; Financial reports

\section{Background of the Study}

The United Arab Emirates (UAE) government aims to diversify the national income resources and decrease its dependency on oil exports. To this end, the UAE is encouraging investment in other sectors. In view of its large capital and natural resources and the high standards of infrastructure, the UAE is a centre for foreign investment [1]. To maintain and protect the investors, the UAE has enacted comprehensive economic regulations and laws to facilitate and regulate investments. Recently, the government of the UAE imposed a mandatory corporate governance code (CGC) for all publicly listed firms which, according to Ananchotikul and Eichengreen [2], could be considered as a tool to protect investors from mismanagement.

Claessens and Yurtoglu [3] defined corporate governance as a collection of mechanisms designed and adopted to control the management's decisions and activities, to positively enhance capital resources. Firms are adopting corporate governance to ensure their accountability to the shareholders and to improve the transparency of financial reports $[2,4,5]$. Other studies found that well-governed firms attract more foreign investors [6,7]. Klapper and Love [8] also regarded corporate governance as a means to secure external finance.

Having older and well established capital markets in other Middle East countries (e.g., in Jordan, corporate governance code was issued in 2005 as per Suwaidan et al., [9]) reduce UAE's capital markets ability to compete with other countries. Since capital markets in UAE are unknown to outside investors, this is because capital markets in the UAE are new compared to other Gulf and Middle East capital markets. Unless good corporate governance regulations have been applied. That also was the recommendation of the International Monetary Funds (IMF) in a recent report (IMF, Country Report No. 13/240, 2013), as there seems to be a need for better corporate governance in the UAE.

In addition, even though prior studies claimed that well-monitored capital markets have become more attractive for foreign investors [7], studies linking the mechanisms with foreign investments seem to be limited particularly in the context of the UAE due to the recent introduction of a corporate governance code (in 2010). To date it is still not known whether the CGC has made positive impacts on the UAE capital markets particularly in terms of attracting foreign investors. This study tries to fill in that gap and figure out whether there is an effect of corporate governance on foreign ownership as empirical evidence is lacking, particularly in the context of UAE.

It is expected that the findings of the study will have policy implications for UAE as corporate governance is still a new issue that requires refining to improve the quality of corporate decisions instead of burden firms with extra costs without reaping its benefits. In addition, the findings of the current study can be applicable in other Gulf countries due to shared economic and social circumstances.

As for the structure of the study, following is the current state of corporate governance in the UAE. Next section offers an extensive literature review on corporate governance. The literature review is used as a basis to derive the study's hypotheses. That is followed by the research methodology. Next section discusses the data analysis and findings. Finally, the present study concludes in the last section.

\section{Corporate Governance Evolution in the UAE}

After the financial crisis in $2007 / 2008$, even if the crisis did not severely affect the Gulf region, those investing in the Emirates requested greater transparency of financial information and better corporate governance [10]. In addition, the International Monetary Fund (IMF) (IMF, Country Report No. 13/240, 2013) reported weaknesses in corporate governance.

Before 2007, corporate governance was regulated indirectly by the

*Corresponding author: Farhan A, Assistant Professor, Higher Colleges of Technology, UAE, Tel: +02 206 4222; E-mail: afarhan@hct.ac.ae

Received September 02, 2018; Accepted October 18, 2018; Published October 25, 2018

Citation: Farhan A, Annuar HAB (2018) Foreign Investment Choices and Corporate Governance Role. Bus Eco J 9: 374. doi: 10.4172/2151-6219.1000374

Copyright: (C) 2018 Farhan A, et al. This is an open-access article distributed under the terms of the Creative Commons Attribution License, which permits unrestricted use, distribution, and reproduction in any medium, provided the original author and source are credited. 
UAE Corporation Act of 1984, the federal law No. (4) of 2000, and the Securities and Commodities Authority (SCA).

Early in 2007, the SCA issued the first corporate governance code for joint stock companies established in the UAE. The corporate governance code clarifies the corporate governance mechanisms that should be applied by the corporations such as board composition, board selection rules, remunerations, duties, subcommittees, and meetings. The strength of the internal control system was ensured besides the internal and external audit requirements. Article 14 of the 2007 corporate governance code reported a unique requirement that the corporations should prepare and publish new reports called the Governance Report on an annual basis. Applying the corporate governance code was voluntary for public joint-stock companies. Publicly listed corporations were given a maximum of three years to reconcile and adhere to the corporate governance code issued in 2007 (UAE Code of Governance, Decision \# 32/R Article 16, 2007).

The UAE Ministry of Economy issued the corporate governance code at the end of 2009, and simultaneously mandated its application by all the companies listed in the financial markets no later than May 2010 (Minister of Economy, No. (518) Article 16, 2009). The Ministerial Resolution No. 518 of 2009 is similar to Decision \# 32/R of 2007, but differs in its scope of application. The former decision is mandatory for corporations listed on the UAE's financial markets.

The corporate governance code has been issued in Ministerial resolution, No. (518) of 2009 (the CGC) which outlines specific and detailed corporate governance requirements that corporations must comply with.

\section{Literature Review and Hypothesis Development}

Based on the agency theory, corporate governance varies among scholars according to the scholars' perspectives [11,12]. Shleifer and Vishny [13] defined corporate governance as all the ways the investors could get their required return on their investments. Donaldson [14] cited a more comprehensive definition of corporate governance based on who defined corporate governance as the whole set of legal, cultural, and institutional arrangements that determine what the corporations can do, how corporations are controlled, how the returns are allocated, and who should bear the risks. Most of the corporate governance definitions are derived from the above definition. For example, Love [15] defined corporate governance as a set of different mechanisms, which ensure that the investors will get a return on their investments.

Based on the agency theory, shareholders and management have a conflict of interest due to differences in their objectives [16]. Therefore, Eisenhardt [17], among other researchers such as Turley and Zaman [18] and Chalevas [19] reported that the principal chooses to invest and incur costs to monitor and control the agents managing activities; these costs are collectively called corporate governance. Lan and Heracleous [20] reported that the principal hire an independent board such as a monitoring body. Separating the control from the decision-making mechanism was introduced by Fama and Jensen [16]. The principal could also invest in an information system which can reduce the information asymmetry through issuance of reports [17].

The investor requires a return on his or her investment that covers the potential risk associated with the investment. The return on the investments is the main concern of the investors as per Jensen and Meckling [21]. Firms could adopt better corporate governance practices to ensure that the firm's investors are well protected against management expropriation. By protecting investors' rights from being expropriated by the management, more investors will be attracted to such firms [8]. One of the shareholders is the foreign investor who chooses companies with effective corporate governance structures [6]. Foreign investors will choose to invest in well-governed firms because the agency costs that could be incurred by the foreign investor are higher than the costs incurred by the local investor [6]. Das [7] also found that well-governed firms would attract more foreign investors.

Numerous studies found that adopting the corporate governance mechanisms could achieve great benefits [8,22]. Researchers investigated corporate governance mechanisms that could attract foreign investors. Firms that apply good corporate governance mechanisms enjoy higher capital inflows from foreigners [23]. Klapper and Love [8] found that firms that seek finance would adopt better corporate governance. La Porta et al. [24] and Kim and $\mathrm{Lu}$ [22] found that more corporate governance reforms improved the capital inflow possibilities from the rich countries toward the countries which need capital. O'Connor et al. [25] supported the conclusion reached by Klapper and Love [8] that good corporate governance practices enjoyed greater investable premiums (the stock market gains accrued by foreign investment). Particularly well governed firms enjoy higher potential to attract foreign investment. Board independence, board size, and audit committee are among the corporate governance mechanisms that have been previously studied.

\section{Board independence effect on foreign investment}

Agency theory assumes that independent non-executive members of the board can generate effective monitoring of the executives [26]. In corporate boards, it is used to include outside members, that is, members who are not internal managers or employees [16]. The CGC in the UAE defined the independent director as a board member who is not a current employee of the firm or within a specific period, and who is not engaged with the firm through business projects or family relations (Minister of Economy, No. 518 of 2009).

Although the effect of board independence on foreign investments has rarely been examined in the literature, the reported results support the assumption that there is a positive effect. Min and Bowman [27] reported that foreign investments increased if the board of directors includes independent members to ensure board effectiveness. Ahmed [10], who examined Saudi Arabian capital markets, has found similar results and concluded that board independence affected foreign investments positively. These studies found strong evidence of a positive effect of board independence on foreign investment, while Yatim et al. [28] found a weak positive effect between the two variables (board independence and foreign investment) in Malaysia. Das [7] reported that board characteristics are one of the basic determinants of foreign ownership because the former reduces monitoring costs.

Contrary to the above results, Suwaidan et al. [9] did not find a significant effect of board independence on foreign investments variables in Jordan. In Jordan, board independence did not play any significant role in attracting foreign investors to the capital markets. Based on that, the following hypothesis is developed:

H1: Board independence has an effect on foreign ownership.

\section{Board size effect on foreign investment}

Board size refers to the number of board members (executives and non-executives) [29]. The CGC did not determine the exact number of board members, instead leaving this decision to the discretion of firms and their respective needs (Minister of Economy, No. (518) Article 3, 2009). 
Researchers found that reasonable board size would be more effective in controlling the firm [30]. On the other hand, large boards could delay communication, which will delay making decisions [31]. Haniffa and Hudaib [12] found that large boards increased the costs in terms of compensation and did not provide effective monitoring.

Large boards as claimed by Sun et al. [32] offer the advantages of increasing the monitoring and advise to the CEO and Chugh et al. [33] added that larger boards create better decisions by providing more resources for these decisions. In addition, Haniffa and Hudaib [12] found that the board size adds more experience. Bushee et al., [34] reported that firms that aim to grow should care about board governance characteristics because foreign investments prefer firms with growth opportunities.

Board size has not been investigated widely in the literature. Nevertheless, authors such as Ahmed [10] and Suwaidan et al. [9] did not find any effect of board size in attracting foreign investments. However, the advantages of board size experiences and other benefits of reasonable board size could positively affect foreign ownership. That gap and the limited research about board size effect on foreign investments encouraged this study to investigate this issue. Due to limited research on the effect of board size on foreign ownership, and the benefits found in related research, the following directional hypothesis states:

\section{H2: Board size has a positive effect on foreign ownership.}

\section{Audit committee structure effect on foreign investment}

The internal audit committee $(\mathrm{AC})$ is a global corporate governance requirement. Audit committees should be composed of a majority of independent directors [35]. In addition, global CGC prefer the audit committee to include at least one financial expert [36].

The importance of the audit committee in affecting foreign investments had been reported in many studies including Yatim et al. [28]. The above authors found that audit committee quality has a significant positive effect on foreign investment. Similarly, Suwaidan et al. [9] found that audit committee size in Jordan has a positive effect on foreign ownership. One of the audit committee characteristics that has been researched by Ahmed [10] is the independence of its members. The researcher reported a positive significant effect on foreign investment given that the audit committee is the financial body that detects earnings management and ensures the accuracy and quality of financial reports. Mangena and Tauringana [37] reported a significant positive effect between audit committee independence and foreign investments in Zimbabwe.

Furthermore, the CGC required audit committee members to be elected from board members who are independent and have financial knowledge or experience. The effect of boards' financial knowledge on foreign investment has been investigated by Yatim et al. [28] finding a significant positive effect of boards' financial knowledge on foreign investments. Although studies that investigated the possible effect of the audit committee on foreign ownership are limited, the indirect benefits of audit committees are many such as better quality of financial reports, decreasing fraud and earnings management, and better value or performance [38-40]. Thus, this study aims to provide a better understanding of audit committee characteristics and its influence on foreign investments. One of the characteristics investigated by Ahmed $[10]$ is the independence of audit committee members. The researcher reported a positive significant effect on foreign investment. Mangena and Tauringana [37] reported a significant positive effect between audit committee independence and foreign investments in Zimbabwe. Based on the agency theory and these findings, and due to the limited literature related to audit committee, the following hypothesis examines the audit committee characteristics:

H3: Audit committee independence has an effect on foreign ownership

Audit committee importance in affecting foreign investments has been reported by many researchers such as Suwaidan et al [9]. They found that audit committee size in Jordan has a positive effect on foreign ownership. Moreover, Yatim et al. [28] found that audit committee quality has a significant positive effect on foreign investment (audit committee quality is measured by many indicators such as existence of a financial expert). Frequent audit committee meetings are an indicator of an active committee which is desired by shareholders [41]. Nevertheless, effective audit committee is the one who meets regularly as per Rickling [42], which improve the quality of their work. Therefore, active audit committee is assumed to be desired by foreign investments. More meetings are found to decrease fraud and earnings management [43]. Vigilant shareholders choose firms where audit committees ensure the accuracy of financial reports and managerial decisions, thus

H4: Audit committee meetings have an effect on foreign ownership.

The effect of audit committee incentives was not related directly to foreign investments in prior research. Indirect benefits of paying incentives to audit committee can be derived from the overall benefits of audit committees as researched and discussed in chapter three. As an example, incentives [44] could motivate an audit committee to decrease opportunistic practices, and thus focus on the short-term performance to achieve the highest possible incentives. Particularly, if the audit committee is paid incentives, they are holding more meetings and performing more work [45]. Other researchers related audit committee incentives to quality of financial reports such as Barua et al. [46]. Even though previous research did not investigate how audit committee incentives could attract foreign ownership, the agency theory introduced the outcome-based incentives to mitigate the agency problem between shareholders and management [21]. Paying more incentives could be a control tool practiced by principals to protect their capitals, which is the main concern of the foreign investor [17] Based on that, the current research aims to investigate the direct effect of audit committee incentives on attracting foreign ownership by testing the following sub-hypothesis:

H5: Audit committee incentives have an effect on foreign ownership.

Financial experts on the audit committee enhances firms' earnings quality, decreases earnings management and improves firms' performance [47]. In addition, Abernathy et al. [48] found strong evidence that the financial background of the audit committee members is related to accurate prediction of future profits. Further, a financial expert as per Abernathy et al., [49] provides financial information on time. Audit committee characteristics are related positively to firms' financial process and information [50]. Particularly, benefits can be found for financial experts on different aspects of the firm, but limited research directly investigated how the benefits of financial experts attract or affect foreign ownership. Thus, this research fills the above gap by building on the agency theory such that more control over the firm would enhance shareholders' confidence. The following subhypothesis is developed: 
H6: Financial expert ratio within the audit committee has an effect on foreign ownership.

\section{Research Methodology}

\section{Source of data}

The annual financial report for four years (2010 to 2013) was obtained for each firm. The variables were acquired from the SCA annual report, firm's annual financial reports, and governance reports. The corporate governance data were retrieved from the governance report that includes all the CGC required information.

The SCA annual report was used to identify the industry type for each firm. From the annual financial reports, data about total assets, foreign ownership and total debt were extracted. The governance reports were used to find board size, information related to board composition, and information associated with AC.

\section{The sample}

This study focuses on publicly listed firms in the capital markets in the UAE, which includes corporations listed in Abu Dhabi Securities Market, and Dubai Financial Market except banks and investment and financial services because they were excluded from the scope of the CGC application.

The listed companies in UAE's financial markets include 127 companies distributed between 12 industry sectors, namely: Real Estate, Banks, Investment and Financial Services, Energy, Telecommunication, Insurance, Industrial, Consumer Staples, Services, Debt Instrument, Electronically Traded Fund, and Transportation.

While collecting the data, there were companies listed after 2011, and thus were excluded. The study focuses on UAE owned companies, thus companies that are owned by other countries, including Gulf countries, were excluded. These companies had 100 percent foreign ownership, which could distort the study's results. That left the researcher with 72 companies as the study sample. More details about the sample are shown in Table 1.

\section{The variables}

This study measures the effect of CGC on foreign investment, so that the dependent variable is foreign ownership. Moreover, the corporate governance mechanisms mandated by the government are included as the independent variables, namely: board independence, board size, and audit committee characteristics. Many control variables are expected to affect foreign ownership such as the risk, firm size, and the industry type. More details about the variables are explained below and summarized in Table 2.

Dependent variable (Foreign investment): As the dependent variable, foreign ownership is calculated as the shares owned by foreigners divided by the total number of outstanding shares [6,7].

Independent variable (CGC mechanisms): The independent variables are determined based on the mechanisms required in the UAE's CGC which are: board independence, board size, and internal audit committee structure.

I. Board Independence was measured as the percentage of independent directors on the board [25,51].

II. Board Size was the total number of directors on the board $[26,30,51]$.

III. Audit Committee Structure was measured by including four characteristics of the audit committee, which are expected to affect the firms' performance. These characteristics are:

1. The independence of the audit committee members, which is measured by dividing the independent members by all the audit committee members as done by Weir et al. [38] and Klein [43].

2. Financial experts measures the proportion of the members within the committee with financial experience, qualifications, or worked previously as an auditor (Archambeault et al., [44] and Rickling, [42]).

3. Number of audit committee meetings is the number of audit committee meetings held during the year $[44,47]$.

\begin{tabular}{|c|c|c|c|c|c|c|}
\hline \multirow[t]{2}{*}{ Financial Market } & \multirow{2}{*}{$\begin{array}{l}\text { Total number of } \\
\text { companies listed }\end{array}$} & \multicolumn{4}{|c|}{ Companies excluded } & \multirow{2}{*}{$\begin{array}{l}\text { Companies included in the } \\
\text { sample }\end{array}$} \\
\hline & & $\begin{array}{c}\text { Foreign } \\
\text { companies }\end{array}$ & New companies & Banks & $\begin{array}{c}\text { Investing and finance } \\
\text { Co. }\end{array}$ & \\
\hline Abu Dhabi & 68 & 5 & 3 & 13 & 3 & 44 \\
\hline Dubai & 59 & 7 & 5 & 11 & 8 & 28 \\
\hline Total & 127 & 12 & 8 & 24 & 11 & 72 \\
\hline
\end{tabular}

Table 1: Sample composition.

\begin{tabular}{|l|l|}
\hline Variable & Measurement \\
\hline Dependent Variables & \\
\hline Foreign ownership & Foreign Ownership=Percent of shares owned by foreigners out all outstanding shares \\
\hline Independent Variables (CGC mechanisms) & \\
\hline Board size & The number of board members \\
\hline Board independence & The proportion of independent directors to total number of board of directors \\
\hline AC independence & The independent members divided by all the AC members \\
\hline AC incentives & The average fees per member that have been received by the AC members during the year \\
\hline AC meetings & Number of meetings held by the committee during the year \\
\hline Financial Expert & The proportion of members within the committee with financial experience or qualifications \\
\hline Control Variables: & \\
\hline Firm size & The natural logarithm of the total assets \\
\hline Industry type & Dummy for each industry sector \\
\hline Risk & Total debt to total assets \\
\hline
\end{tabular}

Table 2: Definition and measurement of variables used in the study. 
4. The audit committee incentives are the average fees per member that have been received by the audit committee members during the year [40].

Control variables: The variables, which have been found to affect firms' performance in previous studies and thus included in the study, are firm size, risk, and industry sector. According to Dalton et al., [52], firm size could be an important factor in affecting foreign investments. It plays a significant role if the firm is large. Large firms could be followed by more analysts [12]. Firm size was included as a control variable by Luo et al., [53] and Min and Bowman [27] when they examined the association between corporate governance and foreign investment.

The risk measured by debt ratio is included as a control variable, because more risk decreases foreign investors' desire to invest in the company. Most of the corporate governance studies have controlled for risk (leverage) [30].

The industry sector has been included in most previous corporate governance studies as a control variable [12]. The study includes eight (8) industry sectors; therefore, seven (7) dummies are created because sectors are categorical variables [54]. Insurance industry sector is considered as the base category.

Statistical models: The statistical model in this study are as follows:

\section{Model 1}

Foreign Ownership $=\beta_{0}+\beta_{1}$ ACINCENTIVES $_{\text {it }}+\beta_{2}$ ACINDEPENDENCE $_{\text {it }}+$ $\beta_{3}$ AC MEETINGS $_{\mathrm{it}}+\beta_{4}$ BOARD INDEPENDENCE $_{\mathrm{it}}+\beta_{5}$ BOARDSIZE $_{\mathrm{it}}+\beta_{6} \mathrm{FI}$ NANCIALEXPERT $_{\text {it }}+\beta_{7}$ FIRM SIZE $_{\text {it }}+\beta_{8}$ RISK $_{\mathrm{it}}+\beta_{9}$ INDUSTRY $_{\text {it }}+\varepsilon_{\text {it }}$

The definition of the variables in the equations are presented in Table 2 above.

Statistical tests: To test the study hypotheses that were developed above, panel data analysis is used. Panel data fixed effect regression models are developed. Since using ordinary pooled cross-sectional modelling violates the assumption of the independence of observations over the study period [53], and can produce biased estimates of coefficients, panel data fixed effect is used. Fixed effect is used when analysing the impact of variables that vary over time [55]. To decide whether to use random effect panel data regression analysis or fixed effect, Hausman test was run using E-views software [56]. The results shown in Table 3 reveal that the Hausman test is significant at $\mathrm{p}<0.05$, thus fixed effect panel analysis was selected to fit the data.

\section{Analysis and Discussion}

\section{Statistical assumptions}

As per George and Mallery [57], there are assumptions that should be tested before running the regression, namely the normal distribution of the residuals, the linearity of the dependent-independent variables relationship, heteroscedasticity, and independence of the variables.

Normality test: To test if the residuals are normally distributed, the normal plots of regression standardised residuals for the dependent variable (foreign ownership) was tested, and indicated a relatively normal distribution [58]. The histogram revealed that the residuals of the dependent variables were normally distributed as shown in Figure 1.

To further investigate the normality of the study variables, the skewness and kurtosis values were calculated (Table 4). As per George and Mallery [57], skewness and kurtosis values close to zero indicate a shape close to normal, but values between \pm 1 are considered excellent and values between \pm 2 are acceptable. As the values shown in Table 4 are within the acceptable range, the data is said to meet normality assumption.

Independence of variables: The independence of the variables was examined by calculating the correlations between independent variables. The correlation coefficients between the independent variables are shown in Table 5. As seen, the correlation coefficients were weak and did not violate the assumption of independence between the variables [54]. Importantly, there was a significant positive association between firm size and the AC meetings, and a significant positive association between AC incentives and firm size $(0.364,0.273$ respectively).

\section{Descriptive analysis of variables}

Table 6 presents descriptive statistics of the study variables from 2010-2013: minimum, maximum, mean and standard deviation. The number of observations for each variable varied due to data availability.

On average, foreigners owned 14.82 percent of the firms. The ownership by foreigners was relatively low if compared to other countries such as Jordan where corporate governance was adopted in 2005; foreigners on average owned 50 percent until 2012 [9].

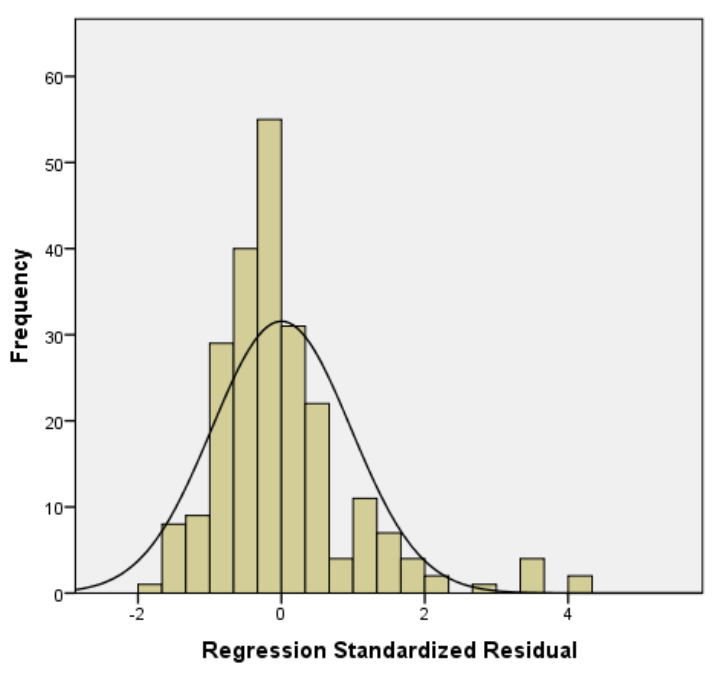

Figure 1: Histogram of foreign ownership residuals.

\begin{tabular}{|l|c|c|c|}
\hline Test Summary & Chi-Sq. Statistic & Chi-Sq. d.f. \\
\hline Cross-section random & 17.934 & 6 & Prob. \\
\hline
\end{tabular}

Table 3: Hausman test.

\begin{tabular}{|c|c|c|c|c|c|}
\hline & N Statistic & Mean Statistic & Std. Deviation Statistic & Skewness Statistic & Kurtosis Statistic \\
\hline Foreign Ownership & 235 & 14.8253 & 22.4486 & 1.721 & 2.318 \\
\hline
\end{tabular}

Table 4: Skewness and Kurtosis values. 
Citation: Farhan A, Annuar HAB (2018) Foreign Investment Choices and Corporate Governance Role. Bus Eco J 9: 374. doi: 10.4172/21516219.1000374

Page 6 of 9

\begin{tabular}{|c|c|c|c|c|c|c|c|c|}
\hline & Variable Name & 1 & 2 & 3 & 4 & 5 & 6 & 7 \\
\hline 1 & Board Independence & & & & & & & \\
\hline 2 & Board Size & $.163^{*}$ & & & & & & \\
\hline 3 & Financial Expert & -0.097 & 0.063 & & & & & \\
\hline 4 & AC Meetings & 0.066 & $.295^{\star \star}$ & -0.052 & & & & \\
\hline 5 & AC Incentives & -0.089 & $.333^{\star *}$ & 0.039 & $.147^{*}$ & & & \\
\hline 6 & AC Independence & $.520^{\star *}$ & 0.068 & 0.028 & 0.055 & $-.147^{*}$ & & \\
\hline 7 & Risk & 0.078 & 0.009 & 0.02 & $.144^{*}$ & -0.089 & 0.064 & \\
\hline 8 & Firm Size & 0.047 & $.396^{* *}$ & 0.067 & $.364^{* *}$ & $.273^{\star *}$ & 0.06 & $.198^{* *}$ \\
\hline
\end{tabular}

Table 5: Correlation matrix.

\begin{tabular}{|c|c|c|c|c|c|}
\hline & $\mathbf{N}$ & Minimum & Maximum & Mean & Std. Deviation \\
\hline Board Independence & 235 & 33.33 & 100 & 69.98 & 19.23 \\
\hline Board Size & 235 & 5 & 18 & 7.68 & 2.02 \\
\hline Financial Expert & 234 & 0 & 100 & 36.16 & 22.69 \\
\hline AC Meetings & 231 & 0 & 13 & 4.37 & 2.07 \\
\hline AC Incentives & 232 & 0 & 45000 & 3755.71 & 7455.28 \\
\hline AC Independence & 234 & 20 & 100 & 84.97 & 16.9 \\
\hline Foreign Ownership & 235 & 0 & 96.3 & 14.82 & 22.44 \\
\hline Firm Size & 235 & 4.73 & 8.09 & 6.2 & 0.66 \\
\hline Risk & 235 & 0.68 & 89.9 & 44.37 & 19.55 \\
\hline
\end{tabular}

Table 6: Descriptive statistics.

The descriptive statistics regarding the GC mechanisms were consistent with the determined regulations in the GC. The GC code does not specify a specific number of board members, but on average, the firms had about eight members on their board, which is similar to other countries [31]. A majority of the boards members were independent as concluded from the average board independence ratio, which was 69.98 percent.

The CGC code stated that the AC should include at least three members, where one of them at least should have financial experience or qualifications. If a firm did not disclose members' qualification or experience, then members were considered not to be financial experts. From Table 6, the mean financial experts' ratio in the ACs was 36.16 percent, which is slightly higher than a third. This shows that the firms complied with the CGC regarding the financial expert ratio. The ACs should meet once every three months as per the CGC; the average number of AC meetings was 4.37. In some cases, committees had more meetings. When firms did not disclose the meetings held during a year, that firm was classified as no meetings being held. Although average incentives paid for the AC member per meeting was AED 3755, there were companies that paid more incentives as evidenced by the standard deviation and the maximum payment of incentives $(45,000)$. It is common for firms not to pay incentives. The mean AC independence was high at 84.96 percent which could be due to the clear statement in the CGC that the majority of the members should be independent. The average debt of firms in the UAE was relatively high. The above result is comparable to other studies such as Klein [43] who found that AC independence in S\&P listed firms is 79 percent.

\section{Regression results for the effect of CGC mechanisms on foreign ownership}

This section examines the effect of each corporate governance mechanism on foreign ownership.

Table 7 provides the panel data regression results for the study's model, where foreign ownership is the dependent variable, the corporate governance mechanisms are the independent variables, and

\begin{tabular}{|l|c|c|c|c|}
\hline Variable & Coefficient & Std. Error & t-Statistic & Prob. \\
\hline AC Incentives & $-3.67 \mathrm{E}-05$ & 0 & -0.212 & 0.833 \\
\hline AC Independence & 0.212 & 0.085 & 2.481 & 0.014 \\
\hline AC Meetings & -1.095 & 0.663 & -1.651 & 0.1 \\
\hline Board Independence & -0.247 & 0.079 & -3.139 & 0.002 \\
\hline Board Size & 3.643 & 0.737 & 4.942 & 0 \\
\hline Financial Expert & -0.021 & 0.056 & -0.379 & 0.705 \\
\hline Firm Size & -4.46 & 3.014 & -1.48 & 0.141 \\
\hline Risk & -0.176 & 0.071 & -2.456 & 0.015 \\
\hline Consumer Staple & 12.04 & 4.455 & 2.703 & 0.007 \\
\hline Energy & 22.45 & 9.093 & 2.469 & 0.014 \\
\hline Services & -1.001 & 4.486 & -0.223 & 0.824 \\
\hline Telecommunication & -1.945 & 9.895 & -0.197 & 0.844 \\
\hline Industrial & 21.579 & 3.718 & 5.804 & 0 \\
\hline Real Estate & 20.576 & 5.693 & 3.614 & 0 \\
\hline Transportation & 43.157 & 6.822 & 6.327 & 0 \\
\hline C & 17.093 & 19.076 & 0.896 & 0.371 \\
\hline R-squared & 0.44 & & & \\
\hline Adjusted R-squared & 0.392 & & & \\
\hline F-statistic & 9.197 & & & \\
\hline Prob. (F-statistic) & 0 & & & \\
\hline Durbin-Watson & 0.131 & & & \\
\hline
\end{tabular}

Table 7: Panel data results for foreign ownership.

the firm size, industry and debt ratio are the control variables.

The model reported a 39.2 percent change in foreign ownership. The overall model was significant $(\mathrm{F}=9.197, \mathrm{p}<0.01)$, meaning that the CGC mechanisms can predict foreign ownership. Two governance mechanisms had a positive significant effect on foreign investments namely AC independence and board size at $\mathrm{p}<0.05(\mathrm{~B}=021$, and 3.643 respectively). Thus, audit committee independence and board size had a positive effect on foreign ownership.

Board independence had a significant negative effect on foreign ownership $(\mathrm{B}=-.247, \mathrm{p}<0.01)$. That means increasing the board independence decreases foreign ownership. Thus, the hypothesis 
on board independence affecting foreign ownership was accepted. However, negative effect is reported.

No significant effect was found for audit committee incentives, meetings and the financial expert ratio on foreign ownership. Based on that, the hypotheses were rejected. Foreign investors are looking to the main corporate governance mechanisms before making investing decisions, while the audit committee structure may not be a significant factor in shaping foreign investors' decisions.

Foreign investors prefer to invest in five industry sectors, namely consumer staples, energy, industrial, real estates, and transportations sectors. The above five industry sectors had a statistically significant positive effect on foreign ownership at $\mathrm{p}<0.05$. The above results are not surprising as it is clear that there is an expansion in UAE's real estate and transportation sectors [1]. Firm size had no effect on foreign ownership. Risk was negatively associated with foreign investments at $\mathrm{p}<0.05(\mathrm{~B}=-0.176)$ which is consistent with Min and Bowman [27].

\section{Discussion on CGC Mechanisms and Foreign Ownership}

The results above revealed that applying the CGC has a significant role in attracting foreign investments. That is consistent with Kim et al. [6] and Haldar and Rao [23] that foreigners are willing to invest in well-governed firms. Mangena and Tauringana [37] and Ahmed [10] found that audit committee independence and size align the agent and principal conflicts. Therefore, foreign investors are positively affected by audit committee independence in the current study. The study indicates that the existence of an independent audit committee enhances foreign investors' confidence in the management decisions.

Board size mechanisms provide the needed experience to investigate and monitor the management decisions. Larger boards are preferable by foreign investors as the analysis results indicate.

The contrary results regarding board independence are inconsistent with other researchers such as Ahmed [10] and Min and Bowman [27]. That contrary result revealed shortcomings in board independence regulations. Board members are classified as independent based on disclosure from the firm side, with no details on how or why that member is considered independent. The artificial classification of board members as independent harms their real duty, which is monitoring the management decisions. More independent members means that they are further away than being involved in the firms activities [59-61]. Though that result is not consistent with previous researchers' results, it indicates that the foreign investors look at corporate governance mechanisms altogether. Foreign investors investigate many other mechanisms and/or board members' individual characteristics and achievements.

\section{Conclusion}

Corporate governance is one of the major concerns for firms nowadays. Countries are encouraging firms to adopt corporate governance mechanisms to enhance monitoring over firms, and at the same time to achieve economic growth.

This study investigated the effect of the CGC on foreign ownership. Particularly, the study aims to investigate if CGC mechanisms (board independence, board size, and audit committee characteristics) have an effect on foreign investment in domestic UAE firms.

To investigate the research objective, the agency theory was used to develop the theoretical framework. The agency theory perspective calls for aligning the interests of the shareholders with the interests of the management by electing independent boards who are qualified to implement major tasks in the firm such as auditing the management decisions. Based on current globalisation and diversification of investor types, firms are not only concerned about their domestic shareholders, but also attracting outside investors. Foreign investors are concerned about the costs that could be incurred to keep their investments safe. Countries that compete to attract investors should employ different mechanisms to achieve that goal.

Using statistical techniques such as panel data regression analysis, the study was based on a sample from the UAE financial market. The list of 72 sampled firms was extracted from public joint stock companies listed in Abu Dhabi Exchange Market and Dubai Financial Market from 2010 to 2013. The financial markets included twelve industry sectors, but the study excluded two sectors due to the exemption from applying the CGC regulations.

The findings indicated the importance of corporate governance in the UAE in attracting foreign ownership. Mainly, board size and AC independence had a significant positive effect on attracting foreign investments. On the other hand, foreign investors, who considered it an indicator of weak supervision, did not prefer board independence.

The current study contributes to the literature related to the professional practice of corporate governance by introducing the role of corporate governance and consequences in the firms. Previously, most corporate governance research was concerned with one objective that is whether implementing corporate governance mechanisms could improve firms' performance. However, this study went a step further and studied the preferences of foreign ownership in absence of firms' performance factor. Furthermore, this research adds to the existing body of literature in the field of corporate governance conditions. Specifically, this study shed light on a country that has applied corporate governance for better foreign investment opportunities.

The results of this study have major implication that is government, firms, and shareholders should specify the goals that are proposed by applying corporate governance and hence, concentrate on the corporate governance mechanisms that could achieve that goal. If the goal is to attract more foreign investors, then it is good to note that foreign investors choose firms with larger board sizes and more independent members in the audit committees. Researchers or policy makers should search for the optimal board size based on firms' own conditions and needs, because one size does not fit all. On the other hand, more board independence was not viewed as favourable by foreign investors. As they may perceive that independent board members are not truly independent. This implies that foreign investors are smart and they thoroughly investigate before investing their money. Therefore, firms should investigate and apply the independence role, which consequently attracts foreign investor not to alienate them.

The current research findings should be interpreted in line with the research limitations, which also highlight further needed research. Such as the effect of political factors during the study period. Politics is expected to change the attitudes of investors. Investors can avoid choosing to invest in a specific industry or country due to politics.

Moreover, the current study limits the factors that could affect foreign ownership by corporate governance mechanisms. As previously mentioned, there are other factors could affect foreign ownership such as infrastructure, availability of resources, and comprehensive investment laws and regulations. This may add to the limitations of the current study, as it does not include these factors. 
Further research could connect the interaction among corporate governance and firms' performance to attracting foreign investments through improving firm's performance.

\section{References}

1. Yearbook UAE (2013) National Media Council. Abu Dhabi, United Arab Emirates.

2. Ananchotikul S, Eichengreen B (2009) Corporate governance reform in emerging markets: How much, why, and with what effects? J Jpn Int Econ 23 : 149-176.

3. Claessens S, Yurtoglu BB (2013) Corporate governance in emerging markets: A survey. Emer Markets Rev 15: 1-33.

4. Abdul Wahab EA, How JC, Verhoeven P (2007) The impact of the Malaysian code on corporate governance: Compliance, institutional investors and stock performance. J Contemp Account Econ 3: 106-129.

5. Tariq YB, Abbas Z (2013) Compliance and multidimensional firm performance: evaluating efficacy of rule - based code of corporate governance. Econ Model 35: 565-575.

6. Kim IJ, Eppler-Kim J, Kim WS, Byun SJ (2010) Foreign investors and corporate governance in Korea. Pac-Basin Financ J 18: 390-402.

7. Das $P(2014)$ The role of corporate governance in foreign investments. App Financ Econ 24: 187-201.

8. Klapper LF, Love I (2004) Corporate governance, investor protection, and performance in emerging markets. J Corp Financ 10: 703-728.

9. Suwaidan M, Abed S, Al-Khoury A.(2013) Corporate governance and nonJordanian share ownership: the case of Amman Stock Exchange. Int J Bus Manage 8: 14

10. Ahmed M (2010) Global financial crisis highlights GCC's policy challenges. In Econ Bull, Carnegie Endowment for International Peace.

11. Gillan SL (2006) Recent developments in corporate governance: an overview. J Corp Financ, 12: 381-402.

12. Haniffa R, Hudaib M (2006) Corporate Governance Structure and Performance of Malaysian Listed Companies. J Bus Financ Account 33: 1034-1062.

13. Shleifer A, Vishny RW (1997) A Survey of Corporate Governance. The Journal of Finance 52: 737-783

14. Donaldson T (2012) The epistemic fault line in corporate governance. Acad Manage Rev 37: 256-271.

15. Love I (2010) Corporate governance and performance around the world: what we know and what we don't. The World Bank Research Observer 26: 42-70.

16. Fama FE, Jensen CM (1983) Separation of Ownership and Control. J Law Econ 26: 301-325

17. Eisenhardt KM (1989) Agency theory: An assessment and review. Acad Manage Rev 14: 57-74.

18. Turley S, Zaman M (2004) The corporate governance effects of audit committees. J Manage Gov 8: 305-332.

19. Chalevas CG (2011) The effect of the mandatory adoption of corporate governance mechanisms on executive compensation. Int J Account 46: 138-174.

20. Lan LL, Heracleous L (2010) Rethinking agency theory: The view from law. Acad Manage Rev 35: 294-314.

21. Jensen MC, Meckling WH (1976) Theory of the firm: Managerial behaviour, agency costs and ownership structure. J Financ Econ 3: 305-360.

22. Kim EH, Lu Y (2013) Corporate governance reforms around the world and cross-border acquisitions. J Corp Financ 22: 236-253.

23. Haldar A, Nageswara Rao SVD (2012) Portfolio flows and governance in corporate India. IUP J Corp Gov 11: 38-44.

24. La Porta R, Lopez-de-Silanes F, Shleifer A, Vishny R (1998) Law and Finance. J Polit Econ 106: 1113-1155.

25. O'Connor T, Kinsella S, O'Sullivan V (2014) Legal protection of investors corporate governance, and investable premia in emerging markets. Int Rev Econ Financ 29: 426-439.
26. Ramdani D, Witteloostuijn VA (2010) The impact of board independence and ceo duality on firm performance: A quantile regression analysis for Indonesia Malaysia, South Korea and Thailand. Brit J Manage 21: 607-626.

27. Min BS, Bowman RG (2015) Corporate governance, regulation and foreign equity ownership: Lessons from Korea. Econ Model 47: 145-155.

28. Yatim P, Iskandar TM, Nga E (2016) Board attributes and foreign shareholdings in Malaysian listed firms. J Manage Gov 20: 147-178

29. O'Connell V, Cramer N (2010) The relationship between firm performance and board characteristics in Ireland. Eur Manage J 28: 387-399.

30. García-Ramos R, García-Olalla M (2011) Board characteristics and firm performance in public founder-and nonfounder-led family businesses. J Fam Bus Strat 2: 220-231.

31. Guest PM (2009) The impact of board size on firm performance: evidence from the UK. Euro J Financ 15: 385-404.

32. Sun J, Lan G, Ma Z (2014) Investment opportunity set, board independence, and firm performance: The impact of the Sarbanes-Oxley Act. Manageria Financ 40: 454-468.

33. Chugh LC, Meador JW, Kumar AS (2011) Corporate governance and corporate performance: evidence from India, J Financ Accountancy.

34. Bushee BJ, Carter ME, Gerakos J (2013) Institutional investor preferences for corporate governance mechanisms. J Manage Account Res 26: 123-149.

35. Fichtner JR (2010) The recent international growth of mandatory audit committee requirements. Int J Disclosure Gov 7: 227-243.

36. Ghafran C, O'Sullivan N (2013) The governance role of audit committees: reviewing a decade of evidence. Int J Manage Rev 15: 381-407.

37. Mangena M, Tauringana V (2007) Disclosure, corporate governance and foreign share ownership on the Zimbabwe stock exchange. J Int Financ Manage Account 18: 53-85.

38. Weir C, Laing D, McKnight PJ (2002) Internal and external governance mechanisms: their impact on the performance of large UK public companies. $J$ Bus Financ Account 29: 579-611.

39. Mohd Saleh N, Mohd Iskandar T, Mohid Rahmat M (2007) Audit committee characteristics and earnings management: Evidence from Malaysia. Asian Rev Account 15: 147-163.

40. Chan RS, Lau CK, Ng AW (2011) Compliance and value relevance of audit committees: evidence from Hong Kong. J Financ Reporting Account 9: 74-97.

41. Méndez CF, García RA (2007) The effects of ownership structure and board composition on the audit committee meeting frequency: Spanish evidence. Corp Gov: Int Rev 15: 909-922.

42. Rickling M (2014) Audit committee characteristics and repeatedly meetingbeating analyst forecasts. Int J Bus 19: 173-191.

43. Klein A (2002) Audit committee, board of director characteristics, and earnings management. J Account Econ 33: 375-400.

44. Archambeault DS, DeZoort FT, Hermanson DR (2008) Audit committee incentive compensation and accounting restatements. Contemporary Account Res 25: 965-992.

45. Eshleman JD, Guo P (2013) Abnormal audit fees and audit quality: The importance of considering managerial incentives in tests of earnings management. Auditing: J Pract Theory 33: 117-138.

46. Barua A, Rama DV, Sharma V (2010) Audit committee characteristics and investment in internal auditing. J Account Publ Policy 29: 503-513.

47. Xie B, Davidson III WN, DaDalt PJ (2003) Earnings management and corporate governance: the role of the board and the audit committee. J Corp Financ 9: 295-316.

48. Abernathy JL, Herrmann D, Kang T, Krishnan GV (2013) Audit committee financial expertise and properties of analyst earnings forecasts. Adv Account 29: 1-11.

49. Abernathy JL, Beyer B, Masli A, Stefaniak C (2014) The association between characteristics of audit committee accounting experts, audit committee chairs and financial reporting timeliness. Adv Account 30: 283-297.

50. Mangena M, Pike R (2005) The effect of audit committee shareholding 
Citation: Farhan A, Annuar HAB (2018) Foreign Investment Choices and Corporate Governance Role. Bus Eco J 9: 374. doi: 10.4172/21516219.1000374

Page 9 of 9

financial expertise and size on interim financial disclosures. Account Bus Res 35: 327-349

51. Adams RB, Mehran H (2012) Bank board structure and performance: Evidence for large bank holding companies. J Financ Intermed 21: 243-267.

52. Dalton DR, Daily CM, Ellstrand AE, Johnson J L (1998) Meta-analytic reviews of board composition, leadership structure, and financial performance. Strat Manage J 19: 269-290.

53. Luo X, Chung CN, Sobczak M (2009) How do corporate governance mode differences affect foreign direct investment in emerging economies? J Int Bus Stud 40: 444-467.

54. Field A (2009) Discovering Statistics Using SPSS, 3rd edition, London: SAGE.

55. Bell A, Jones K (2015) Explaining fixed effects: Random effects modeling of time-series cross-sectional and panel data. Polit Sci Res Meth 3: 133-153.
56. Greene WH (2008) Econometric analysis, (6th edn.) Upper Saddle River, NJ: Prentice Hall.

57. George D, Mallery P (2008) SPSS for Windows Step by Step, (8th edn.), US Pearson.

58. Coakes SJ, Ong C (2011) SPSS: analysis without anguish: version 18 for windows, Australia: Wiley.

59. International Monetary Fund (2013) United Arab Emirates: Selected Issues, IMF Country report No. 13/240. Washington, D.C. (July)

60. Minister of Economy (2009) United Arab Emirates. Ministerial resolution No. (518) of 2009.

61. UAE code of governance: Securities and Commodities Authority Chairperson (2007) Decision No. (R/23) on Corporate Governance Code for Joint-Stock Companies and Institutional Discipline Criteria. 